\title{
PENGARUH KECERDASAN EMOSIONAL TERHADAP KINERJA PEGAWAI PT. INDONESIA COMNETS PLUS DI BANDUNG
}

\author{
Silmy Amilia \\ Universitas Pendidikan Indonesia \\ silmiamalia@student.upi.edu \\ Ridwan Purnama \\ Universitas Pendidikan Indonesia \\ ridwanpurnama@upi.edu
}

\begin{abstract}
ABSTRAK
Kemajuan ilmu pengetahuan dan teknologi telah mendorong industri telekomunikasi menjadi berkembang dengan cepat yang berdampak pada persaingan dan berdampak pula pada kinerja pegawai yang rendah. Salah satunya adalah pegawai PT. Indonesia Comnets Plus Bandung. Hal tersebut membuat PT. Indonesia Comnets Plus Bandung menciptakan strategi untuk meningkatkan kinerja pegawai dengan meningkatkan soft skill pegawainya mengenai kecerdasan emosional. Penelitian ini bertujuan untuk 1) memperoleh temuan mengenai kecerdasan emosional pada pegawai PT. Indonesia Comnets Plus Bandung, 2) memperoleh temuan mengenai kinerja pegawai di PT. Indonesia Comnets Plus Bandung, 3) memperoleh temuan mengenai seberapa besar pengaruh kecerdasan emosional terhadap kinerja pegawai di PT. Indonesia Comnets Plus Bandung baik secara simultan maupun parsial. Objek penelitian ini adalah pegawai PT. Indonesia Comnets Plus Bandung. Variabel bebas dalam penelitian ini adalah kecerdasan emosional dan variabel terikat yaitu kinerja pegawai dengan jenis penelitian yang digunakan adalah deskriptif, verifikatif, dan metode yang digunakan adalah explanatory survey dengan teknik sampel jenuh dengan jumlah sampel 48 responden. Teknik analisa data yang digunakan adalah regresi liniear sederhana dengan alat bantu software komputer SPSS 18.0 for windows. Hasil yang diperoleh dalam penelitian menyatakan bahwa kecerdasan emosional berpengaruh terhadap kinerja pegawai sebesar 60,4\%. Dari hasil penelitian terhadap pengujian hipotesis dapat diketahui bahwa kecerdasan emosional memiliki pengaruh yang positif terhadap kinerja pegawai.
\end{abstract}

Kata kunci : kecerdasan emosional, kinerja pegawai Kemajuan ilmu pengetahuan dan teknologi telah mendorong dunia industri telekomunikasi menjadi berkembang dengan cepat. Pertumbuhan industri telekomunikasi pada 2015 diperkirakan naik sebesar 7\%-10\% atau hampir sama dengan tahun sebelumnya. Banyaknya perusahaan telekomunikasi tersebut menuntut setiap perusahaan untuk memiliki keunggulan kompetitif agar mampu bersaing dengan kompetitor lainnya, baik dari faktor sumber daya manusianya ataupun produk dan atau jasa yang ditawarkannya.

Kenyataanya kualitas sumber daya manusia di Indonesia masih tergolong rendah, tidak terkecuali pada industri telekomunikasi. Hal ini disebabkan karena rendahnya tingkat pendidikan serta rendahnya softskill yang dimiliki. Hal ini dipertegas oleh penelitian Yopines Ansen (2004:11) yang menjelaskan bahwa rendahnya kualitas sumber daya manusia disebabkan masih rendahnya kemampuan sumber daya manusia tersebut baik mengenai pengetahuan, keterampilan, maupun sikap sehingga masih perlu dikembangkan.

Salah satu perusahaan telekomunikasi yaitu PT. Indonesia Comnets Plus Bandung sebagai penyedia jaringan (internet), jasa, serta content telekomunikasi yang berbasis fiber optic backbone yang didukung oleh jaringan berbasis internet protocol juga tidak terlepas dari permasalahan sumber daya manusia. Berhasil atau gagalnya suatu perusahaan bergantung pada sejauh mana kualitas sumber daya manusianya. (Rivai, 2011:4).

Untuk mengetahui seberapa baik kinerja pegawai, perusahaan perlu melakukan penilaian kinerja atau performance appraisal. Maltis dan John H.Jackson (2010:320) menjelaskan bahwa penilaian kinerja adalah proses menentukan seberapa baik pegawai melakukan pekerjaannya terhadap standar kerja dan mengkomunikasikan informasi tersebut kepada mereka. Penilaian kinerja yang dilakukan di PT. Indonesia Comnets Plus Bandung ini dilakukan setiap satu tahun sekali. Berikut Tabel 1.1 yang menunjukkan hasil penilaian kinerja pegawai PT. Indonesia Comnets Plus Bandung.

TABEL 1.1

RATA-RATA PENILAIAN KINERJA

PEGAWAI PT. INDONESIA COMNETS

PLUS BANDUNG

(Dalam Persen) 


\begin{tabular}{|l|c|c|c|}
\hline UKURAN & $\begin{array}{c}\text { Tahun } \\
\mathbf{2 0 1 2}\end{array}$ & $\begin{array}{c}\text { Tahun } \\
\mathbf{2 0 1 3}\end{array}$ & $\begin{array}{c}\text { Tahun } \\
\mathbf{2 0 1 4}\end{array}$ \\
\hline Tinggi & 55.95 & 56.40 & 55.51 \\
\hline Sedang & 31.40 & 29.46 & 29.17 \\
\hline Rendah & 12.65 & 14.14 & 15.33 \\
\hline
\end{tabular}

Berdasarkan Tabel 1.1 penilaian kinerja pegawai PT. Indonesia Comnets Plus Bandung selama 3 tahun terakhir relatif mengalami penurunan pada kategori pegawai berkinerja rendah. Berdasarkan data di lapangan, penurunan kinerja ini terjadi disebabkan karena terjadi penurunan pada aspek penilaian mengenai menunjukkan keterampilan manajemen, mengenali kelemahan diri, keterampilan menyelesaikan masalah serta memberikan saran kepada perusahaan. Faktor-faktor tersebut diindikasi sebagai penyebab fluktuatifnya kinerja pegawai yang dihasilkan.

Banyak faktor yang mempengauhi kinerja pegawai, seperti yang dikemukakan oleh Sutermeister dalam Sedarmayanti (2009:83) bahwa kinerja dipengaruhi oleh faktor kemampuan dan motivasi. Faktor kemampuan bukan hanya mengenai pengetahuan saja tetapi juga skill. Kemampuan yang berupa pengetahuan (knowledge) dapat terbentuk melalui pendidikan dan pengalaman, sedangkan ketrampilan (skill) terbentuk dari latihan-latihan.

Keterampilan agar seseorang dapat mengelola diri sendiri merupakan keterampilan mengenai kecerdasan emosional. Kecerdasan emosional dapat membantu seseorang dalam menggunakan kemampuan kognitifnya (pengetahuan) sesuai dengan potensi yang dimilikinya secara maksimum. Salah satu bentuk pembinaan yang dilakukan perusahaan untuk meningkatkan kecerdasan emosional pegawai, yaitu dengan mengadakan beberapa program pembinaan mengenai pengelolaan emosi.

Kecerdasan emosional pegawai perlu digali dan dikembangkan agar mampu memberikan dampak positif terhadap kinerja serta memudahkan perusahaan dalam mencapai tujuannya. Seperti yang dikemukakan oleh Shahhosseini Mohmmad, Abu Daud Silong, Ismi Arif Ismaill, dan Jegak nak Uli (2012:245) bahwa kecerdasan emosional merupakan kunci untuk meningkatkan kinerja pegawai. Seseorang yang memilki kecerdasan emosional yang baik akan berdampak pada karir yang diperoleh. Selain itu Yadav Nidhi (2011:258) menyebutkan bahwa seseorang dengan kecerdasan emosional yang tinggi akan memperoleh hasil kerja yang lebih baik dibandingkan dengan seseorang yang memiliki kecerdasan emosional rendah.

Selain itu Jofri Hasan (2010:71) menyebutkan bahwa kecerdasan emosional memiliki peran penting di tempat kerja. Pegawai yang memiliki kecerdasan emosional yang baik akan berdampak pada pekerjaanya.

1. Adapun tujuan penelitian ini adalah 1) Untuk memperoleh temuan mengenai kecerdasan emosional pegawai di PT. Indonesia Comnets Plus Bandung.

2. Untuk memperoleh temuan mengenai kinerja pegawai di PT. Indonesia Comnets Plus Bandung.

3. Untuk memperoleh temuan mengenai pengaruh kecerdasan emosional terhadap kinerja pegawai di PT. Indonesia Comnets Plus Bandung.

\section{KAJIAN PUSTAKA}

Istilah kecerdasan emosional pertama kali dikemukakan oleh psikolog Peter Salovey dari Harvard University dan John Mayer dari University of New Hampshire pada tahun 1990 untuk menerangkan kualitas-kualitas emosional yang tampaknya penting bagi keberhasilan seseorang. Kecerdasan intelektual berbeda dengan kecerdasan emosional. Seseorang yang memiliki kecerdasan emosional yang baik akan menggunakan pemikirannya untuk mengelola emosi bukan dikelola oleh emosi.

Goleman (2009:45) menyatakan bahwa kecerdasan emosi merupakan kemampuan seseorang mengatur kehidupan emosinya dengan intelegensi, menjaga keselarasan emosi dan pengungkapannya melalui keterampilan emosi kesadaran diri, pengendalian diri, motivasi diri, empati, dan keterampilan sosial.

Selanjutnya McPheat Sean (2010:9) mengatakan bahwa kecerdasan emosional kemampuan untuk menyadari emosi diri sendiri dan emosi orang lain dan kemudian menggunakan pengetahuan itu untuk mengelola emosi sehingga dapat mendorong keberhasilan bukan penyebab hambatan.

Dari beberapa pengertian yang dikemukakan di atas, maka kecerdasan emosional merupakan suatu kecakapan seseorang dalam mengelola emosinya baik pada dirinya sendiri maupun terhadap orang lain dan memanfaatkannya untuk memotivasi dirinya. Pengenalan diri sendiri maupun pengenalan pada orang lain ini adalah pengenalan atas potensi maupun kelemahan dalam diri yang menyebabkan seseorang mampu menempatkan diri ketika berhubungan dengan orang lain. Seseorang yang memiliki kemampuan kecerdasan emosional tinggi akan mampu mengenal dirinya sendiri, mampu berpikir rasional dan berperilaku positif serta mampu menjalin hubungan sosial yang baik karena didasari pemahaman emosi orang lain.

Terdapat beberapa ciri-ciri yang mengindikasikan bahwa seseorang memiliki kecerdasan emosional. Goleman (2009:57) 
menyatakan bahwa secara umum ciri-ciri seseorang memiliki kecerdasan emosi adalah mampu memotivasi diri sendiri, bertahan menghadapi frustasi, mengendalikan dorongan hati dan tidak melebih-lebihkan kesenangan, mengatur suasana hati dan menjaga agar beban stres tidak melumpuhkan kemampuan berfikir serta berempati dan berdoa. Lebih lanjut Goleman (2009:57) merinci aspek-aspek kecerdasan emosi secara khusus, yaitu mengenali emosi diri, mengelola emosi, memotivasi diri sendiri, mengenali emosi orang lain, dan keterampilan sosial.

Kelangsungan hidup suatu organisasi salah satunya tergantung pada kinerja karyawan dalam melaksanakan pekerjaannya. Pencapaian tujuan organisasi menjadi kurang efektif apabila banyak karyawannya tidak berprestasi. Mangkunegara (20011:67), berpendapat bahwa kinerja adalah hasil kerja secara kualitas dan kuantitas yang dicapai oleh seorang pegawai dalam melaksanakan tugasnya sesuai dengan tanggung jawab yang diberikan kepadanya.

Gary Dessler (2010:322) menyatakan

bahwa "Penilaian kinerja berarti mengevaluasi kinerja karyawan saat ini dan atau di masa lalu relatif terhadap standar prestasinya". Sedangkan Maltis dan John H.Jackson (2010:320) menjelaskan bahwa penilaian kinerja atau performance appraisal adalah proses menentukan seberapa baik karyawan melakukan pekerjaannya terhadap standar kerja dan mengkomunikasikan informasi tersebut kepada mereka.

Kinerja seseorang dapat diketahui denagn cara mengadakan penialain terhadap pekerjaan seseorang. Kinerja perlu dirumuskan guna dijadikan tolak ukur terhadap pencapaian seseorang dengan apa yang menjadi tanggungjawabnya.

Menurut Gomez-Mejia, Balkin, dan Cardy (2012:225) mengemukakan bahwa dimensi kinerja terdiri dari: Quality of work (Kualitas pekerjaan), Quantity of work performed (Kuantitas pekerjaan yang dilakukan), Interpersonal effectiveness (Efektivitas interpersonal), Competencies (Kompetensi).

Kecerdasan emosional memiliki pengaruh positif terhadap kinerja pegawai. Seperti Jorfi Hassan (2010:63) menyatakan bahwa kecerdasan emosional merupakan faktor penting dalam menentukan keberhasilan hidup serta berperan dalam membentuk interaksi antara manager dan karyawan di lingkungan kerja. Maka dalam penelitiannya, Jorfi Hassan (2010:70) menemukan adanya pengaruh yang signifikan antara kecerdasan emosional terhadap kinerja seorang karyawan. Kecerdasan emosional tersebut memberi dampak positif terhadap kualitas kinerja seseorang.

\section{Kerangka Pemikiran}

Pengelolaan sumber daya manusia yang baik menjadi bagian yang sangat penting dari tugas manajemen perusahaan. Rivai (2011:1) mengemukakan bahwa manajemen sumber daya manusia adalah salah satu bidang dari manajemen umum yang meliputi segi-segi perencanaan, pengorganisasian, pelaksanaan dan pengendalian.

Pengembangan sumber daya manusia dilakukan dengan harapan agar dapat meningkatkan kualitas sumber daya manusia yang ada serta meningkatkan kemampuan yang dimiliki sumber daya manusianya sehingga kinerja yang dihasilkan akan optimal.

Seperti yang dikemukakan oleh Sedarmayanti (2009:26), bahwa pengembangan sumber daya manusia merupakan proses peningkatan kualitas sumber daya manusia mengenai kemampuan dan keterampilan melalui pendidikan atau pelatihan. Kecerdasan emosional merupakan bagian dari keterampilan yang perlu dikembangkan. Salovey dalam Goleman (2002:57) bahwa keterampilan interpersonal dan keterampilan intrapersonal merupakan dasar untuk mengungkapkan kecerdasan emosional. Kecerdasan emosional memiliki peran penting dalam keberhasilan di tempat kerja. Berdasarkan penelitian Kahtani (2013), kecerdasan emosional karyawan akan berdampak terhadap apa yang dilakukan oleh karyawan tersebut sehingga mempengaruhi kinerja yang akan dicapai. Berdasarkan penjelasan di atas, maka dapat dibuat dalam suatu kerangka pemikiran seperti pada Gambar 2.1.

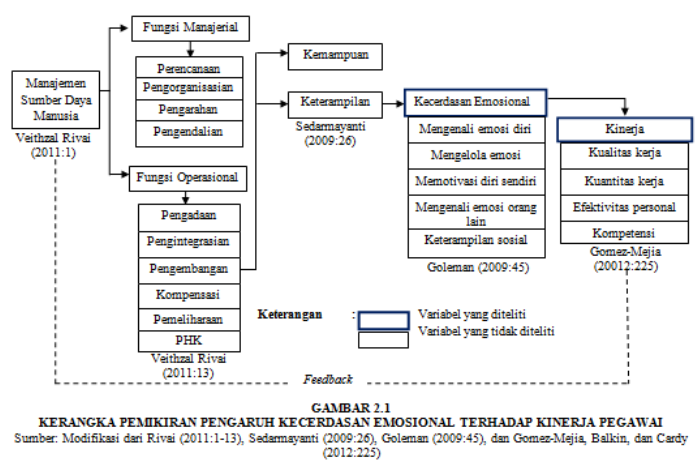

\section{METODE PENELITIAN}

Penelitian ini menganalisis pengaruh kecerdasan emosional terhadap kinerja pegawai pada PT. Indonesia Comnets Plus Bandung. Variabel bebas (independent variable) dalam penelitian ini adalah kecerdasan emosional yang terdiri dari mengenali emosi diri (self-awareness), mengelola emosi (self-regulation), memotivasi diri sendiri (motivation), mengenali emosi orang lain (emphaty), dan keterampilan sosial (social skill). Sedangkan variabel terikat (dependent variable) adalah kinerja pegawai yang terdiri dari 
quality of work (kualitas pekerjaan), quantity of work performed (kuantitas pekerjaan yang dilakukan), interpersonal effectiveness (efektivitas interpersonal), competencies (kompetensi).

Penelitian ini dilakukan di PT. Indonesia Comnets Plus Bandung. Adapun yang menjadi objek penelitian adalah tanggapan responden tentang kecerdasan emosional terhadap kinerja pegawai di PT. Indonesia Comnets Plus Bandung, sedangkan yang menjadi subjek dalam penelitian adalah pegawai pada PT. Indonesia Comnets Plus Bandung. Penelitian ini dilakukan dalam jangka waktu kurang dari satu tahun, maka metode penelitian yang dipergunakan adalah cross sectional method.

Teknik sampel yang digunakan dalam penelitian ini adalah sampling jenuh. Istilah lain sampel jenuh adalah sensus, dimana semua anggota populasi dijadikan sampel. Berdasarkan pendapat di atas, dikarenakan jumlah pegawai di PT. Indonesia Comnets Plus Bandung kurang dari 100 orang, maka sampel yang diambil adalah seluruh jumlah populasi atau jumlah pegawai di PT. Indonesia Comnets Plus Bandung sebanyak 48 orang.

Teknik pengumpulan data yang digunakan adalah studi kepustakaan, dokumentasi, wawancara, kuesioner. Sedangkan teknik analisis data yang dilakukan adalah analisis deskriptif dan verifikatif.

\section{HASIL PENELITIAN DAN PEMBAHASAN}

\section{Uji Normalitas}

Hasil perhitungan liniearitas terdapat pada Tabel 4.17 berikut ini.

\begin{tabular}{|c|c|c|}
\hline \multicolumn{3}{|c|}{$\begin{array}{c}\text { TABEL 4.17 } \\
\text { UJI NORMALITAS } \\
\text { One-Sample Kolmogorov-Smirnov Test }\end{array}$} \\
\hline & & $\begin{array}{c}\text { Unstandardized } \\
\text { Residual }\end{array}$ \\
\hline N & & 48 \\
\hline \multirow[t]{2}{*}{ Normal Parameters 3,0} & Mean & .0000000 \\
\hline & Std. Deviation & 4.35786222 \\
\hline \multirow[t]{3}{*}{ MostExtreme Differences } & Absolute & .101 \\
\hline & Positive & .101 \\
\hline & Negative & -.078 \\
\hline Kolmogorov-Smirnov Z & & .698 \\
\hline Asymp. Sig. (2-tailed) & & .715 \\
\hline
\end{tabular}

Pada Tabel 4.17 menunjukan bahwa hasil uji normalitas dengan Kolmogorov-Smirnof Test diperoleh nilai KSZ sebesar 0,695 Asymp.Sig. sebesar 0,715 atau > 0,05 maka dapat disimpulkan data tersebut berdistribusi normal.

Setelah diketahui bahwa variabel kecerdasan emosional dan variabel kinerja berdistribusi normal, maka selanjutnya perlu diketahui apakah kedua variabel tersebut benarbenar memiliki hubungan Linear, untuk itu perlu dilakukan uji lineritas regresi variabel $\mathrm{X}$ atas variabel Y. Pengujian lineritas ini dimaksudkan untuk mengetahui kemungkinan adanya hubungan Linear antara kecerdasan emosional terhadap kinerja. Hasil analisis data diperoleh output Anova pada Tabel 4.18 sebagai berikut:

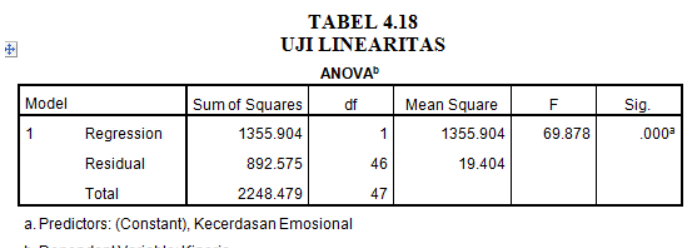

Berdasarkan hasil pengujian menggunakan uji $F_{\text {test }}$ didapatkan $F_{\text {hitung }}$ sebesar 69,878 dengan tingkat signifikansi $0,000 \leq 0,05$ artinya variabel kecerdasan emosional (X) secara keseluruhan model tersebut sudah fit dan terdapat hubungan antara variabel kecerdasan emosional terhadap kinerja sehingga regresi bisa dipakai untuk memprediksi kinerja karyawan. Berdasarkan hasil pengujian Linearitas, maka dapat dikatakan bahwa data yang dihasilkan memenuhi asumsi Linearitas.

Untuk melihat lebih jelas mengenai liniearitas data tersebut, dapat dilihat dalam grafik Scater-Plot pada Gambar 4.3

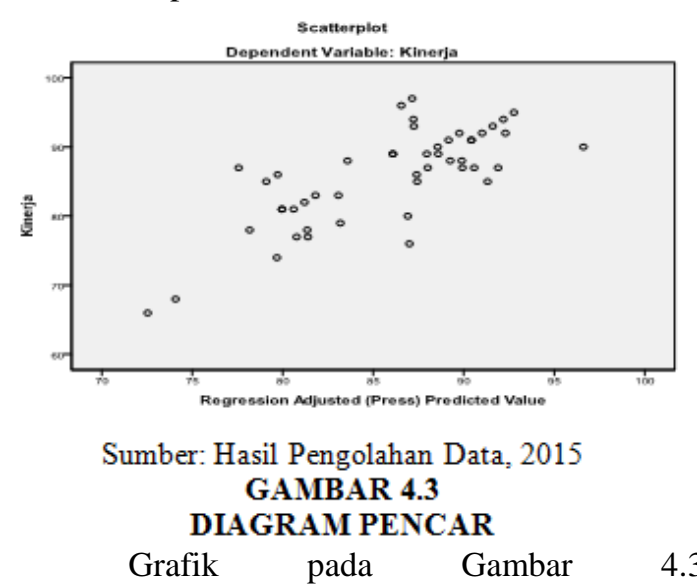
menggambarkan bahwa titik-titik pada diagram pencar di atas menyebar berbentuk pola dari kiri bawah menuju kanan. Dari garis tersebut dapat diketahui kovaransi antara $\mathrm{X}$ dan $\mathrm{Y}$ sifatnya searah, dalam arti bahwa apabila $\mathrm{X}$ berubah semakin besar maka $\mathrm{Y}$ pun berubah semakin besar, hal ini menunjukan bahwa ada hubungan positif antara variabel X dan Y. Berdasarkan hasil uji asumsi klasik yang telah dilakukan, maka penelitian ini dapat diolah menggunakan analisis regresi liniear sederhana.

\section{Analisis Regresi Liniear Sederhana}

Perhitungan persamaan regresi liner sederhana dilakukan dengan menggunakan bantuan software SPSS 18.0 for windows. Hasil perhitungan analisis regresi sederhana dapat dilihat dalam Tabel 4.22 


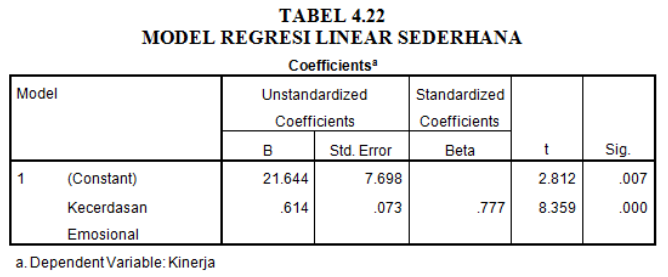

Berdasarkan hasil perhitungan yang terdapat pada Tabel 4.22 diperoleh persamaan regresi sederhana antara kecerdasan emosional dan kinerja pegawai sebagai berikut.

$$
\mathrm{Y}=21,644+0,614 \mathrm{X}
$$

Dari persamaan regresi tersebut dapat diartikan sebagai berikut:

1. Konstanta a sebesar 21,644 memiliki arti bahwa ketika variabel dependen taksiran pada saat $X=0$, maka regresi memotong sumbu Y pada titik 21,644, atau dapat diartikan bahwa jika variabel X (Kecerdasan Emosional) sama dengan nol atau tidak mengalami perubahan, maka nilai kinerja pegawai adalah sebesar 21,644.

2. Pada persamaan regresi di atas, nilai b atau koefisien regresi pada kinerja pegawai bertanda positif $(+)$. Hal ini menggambarkan pengaruh positif antara variabel $\mathrm{X}$ (Kecerdasan Emoisonal) dengan variabel Y (Kinerja Pegawai). Artinya, setiap adanya kenaikan kecerdasan emosional, maka kinerja pegawai akan naik, sebaliknya jika kecerdasan emosional turun maka kinerja pegawai akan turun sebesar 0,614 satu satuan nilai.

\section{Uji F}

Berikut ini adalah hasil perhitungan statistik uji $\mathrm{F}$ yang dilakukan dengan bantuan SPPS 18.0 for windows.

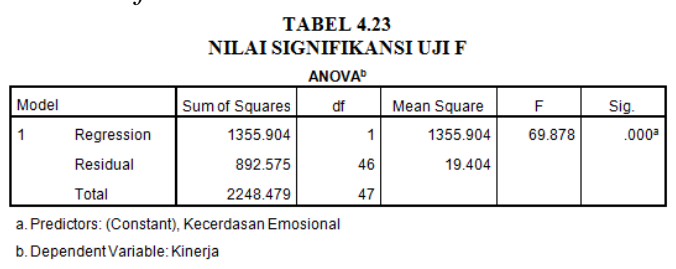

Berdasarkan hasil perhitungan pada Tabel 4.23, diperoleh data yang menunjukkan bahwa $F_{\text {hitung }}$ sebesar 69,878 sedangkan nilai $F_{\text {tabel }}$ yang diperoleh dari Tabel $\mathrm{F}$ dengan 48 responden yaitu pada $a=0,05$ adalah 4,052 . Karena Fhitung $>$ Ftabel, yaitu 69,878 > 4,052, maka $\mathrm{H}_{\mathrm{o}}$ ditolak. Dengan demikian dapat disimpulkan bahwa hipotesis dalam penelitian ini yaitu $\mathrm{H}_{\mathrm{o}}$ ditolak dan $\mathrm{H}_{\mathrm{a}}$ diterima, sehingga terdapat pengaruh positif dari kecerdasan emosional terhadap kinerja pegawai PT. Indonesia Comnets Plus Bandung.

\section{Koefisien Determinasi}

$$
\mathrm{KD}=\mathrm{r}^{2} \times 100 \%
$$

KD

$$
\begin{aligned}
& =r^{2} \times 100 \% \\
& =r^{2} \times 100 \% \\
& =(0,777)^{2} \times 100 \% \\
& =0,604 \times 100 \% \\
& =60,4 \%
\end{aligned}
$$

Dari hasil penghitungan koefisien determinasi untuk kecerdasan emosional (X) terhadap kinerja pegawai (Y) adalah $60,4 \%$. Dengan kata lain kinerja pegawai dipengaruhi $60,4 \%$ oleh kecerdasan emosional sedangkan $39,6 \%$ dipengaruhi oleh faktor-faktor lainnya diluar kecerdasan emosional. Berikut ini rekapitulasi pengaruh kecerdasan emosional terhadap kinerja.

\section{KESIMPULAN DAN REKOMENDASI KESIMPULAN}

1. Gambaran mengenai kecerdasan emosional pada pegawai di PT. Indonesia Comnets Plus Bandung dapat dilihat dari dimensidimensinya yang terdiri dari ranah intrap ribadi, ranah antar pribadi, ranah penyesuaian diri, ranah pengendalian stress, dan ranah suasana hati. Hal ini menunjukkan bahwa kecerdasan emosional yang dimiliki oleh pegawai sudah cukup tinggi (baik) akan tetapi kecerdasan emosional ini masih perlu ditingkatkan serta dipertahankan. Kecerdasan emosional memberikan kontribusi yang baik terhadap kinerja pegawai. Jika seseorang memiliki kecerdasan emosional yang baik, maka dia akan dapat mengatur potensi yang dimilkinya secara optimal sehingga akan menghasilkan kinerja yang optimal.

2. Gambaran mengenai kinerja pegawai di PT. Indonesia Comnets Plus Bandung dapat dilihat dari dimensi-dimensinya yang terdiri dari kualitas pekerjaan, kuantitas pekerjaan yang dilakukan, efektivitas interpersonal, dan kompetensi. Hal ini menunjukkan bahwa kinerja yang dihasilkan oleh pegawai sudah tinggi (baik) akan tetapi belum optimal sehingga ini masih perlu ditingkatkan serta dipertahankan. Kinerja pegawai yang tinggi akan berdampak pada pencapaian tujuan perusahaan, sehingga diharapkan seluruh pegawai menujukkan kinerja yang optimal.

3. Kecerdasan emosional yang dimiliki pegawai PT. Indonesia Comnets Plus Bandung mempunyai pengaruh secara langsung atau simultan sebesar 60,4\% terhadap kinerja pegawai, sedangkan $39,6 \%$ dipengaruhi faktor-faktor lainnya. Korelasi atau hubungan antara kecerdasan emosional dengan kinerja pegawai memperoleh skor 
sebesar sebesar 0,777 (positif) yang berarti terdapat hubungan yang kuat antara kecerdasan emosional terhadap kinerja.

\section{REKOMENDASI}

1. Berdasarkan taggapan responeden karyawan mengenai variabel kecerdasan emosional menunjukkan bahwa pegawai memilki kecerdasan emosional yang cukup baik, namun masih ada beberapa penilaian responden terhadap kecerdasan emosional yang masih rendah yaitu pada ranah pengendalian stress. Oleh karena itu pelatihan-pelatihan mengenai manajemen stress dapat menjadi salah satu solusi agar pegawai dapat mengatasi rasa stress yang timbul akibat pekerjaanya, selain itu melakukan acara gathering atau rekreasi seluruh pegawai secara berkala dapat meminimalisir rasa stress yang timbul.

2. Berdasarkan taggapan responeden karyawan mengenai variabel kinerja menunjukkan bahwa pegawai memiliki kinerja yang tinggi (baik), namun masih ada beberapa penilaian responden terhadap kinerja yang masih rendah yaitu pada dimensi kuantitas pekerjaan yang dilakukan. Pada dasarnya hampir seluruh pegawai dapat menyelesaikan pekerjaannya secara tepat waktu dan sesuai target kerja. Namun agar pegawai dapat mengerjakan pekerjaan melebihi target yang telah ditentukan, pegawai perlu diberikan motivasi yang lebih agar terpacu untuk mengerjakan pekerjaannya melebihi target yang telah ditentukan. Seperti dengan memberikan insentif, reward, promosi jabatan.

3. Hasil penelitian menyatakan bahwa kecerdasan emosional berpengaruh positif terhadap kinerja pegawai, maka penulis merekomendasikan agar pihak PT. Indonesia Comnets Plus Bandung dapat mempertahankan, menjaga, mengawasi dan dapat meningkatkan kinerja pegawai melalui pembinaan kecerdasan emosional demi mewujudkan tujuan perusahaan.

4. Bagi peneliti selanjutnya yang berkaitan dengan kinerja pegawai diharapkan agar mencari faktor lain yang dapat atau lebih signifikan dalam hal mempengaruhi kinerja pegawai. Selain itu, penelitian ini diharapkan dapat dijadikan sebagai dasar dalam melakukan penelitian mengenai kecerdasan emosional dengan indikator serta objek yang berbeda dengan menggunakan alat ukur yang lebih tepat untuk mengetahui besarnya kecerdasan emosional. Penulis mengakui bahwa pemilihan alat ukur khususnya untuk variabel kecerdasan emosional ini kurang tepat dan kurang valid dalam mengukur kecerdasan emosional.

\section{DAFTAR PUSTAKA}

Arikunto, Suharsimi. 2009. Dasar-Dasar Evaluasi Pendidikan. Jakarta: Bumi Aksara. 2010. Prosedur Penelitian Suatu Pendekatan Praktik. Jakarta; Rineka Cipta

Badeni. 2013. Kepemimpinan dan Perilaku Organisasi. Bandung: CV. Alfabeta

Chatab, Nevizond. 2009. Mengawal Pilihan Rancangan Organisasi, Organization Theory, Design \& Structured Network. Bandung: CV. Alfabeta.

Dessler Gary. 2010. Human Resources Management $10^{\text {th }}$ edition. Prentice Hall Inc: Upper Saddle River New Jersey.

Dwi, Prasetyo Sunar. 2010. Tes IQ dan EQ Plus. Jogjakarta: BukuBiru.

Goleman, Daniel. 2009. Kecerdasan Emosional: Mengapa EI lebih penting dari IQ. Penerjemah: T. Hermaya. Jakarta: Gramedia Pustaka Utama.

Gomez-Mejia, Luis R and David B. Balkin and Robert L. Cardy. 2012. Managing Human Resources. United States: Pearson Education, Inc., publishing as Prentice Hall.

Husein Umar. 2008. Metode Riset Bisnis. Jakarta: PT.Gramedia Pustaka Utama

Jackson, Sherri L. 2012. Research Method: A Modular Approach 2nd Edition. Wadswort/Cengange Learning

Kravitz, S. Michael dan Susan D. Schubert. 2010. Emotional Intelligence Works: Think, Be and Work Smarter. USA: Axzo Press.

Malhotra, Naresh K. 2009. Riset Pemasaran Pendekatan Terapan Jilid 1. Jakarta:PT Index.

Maltis, Robert L dan John H.Jackson. 2010. Human Resources Management $13^{\text {th }}$ edition. US: Cengage Learning

Mangkunegara, A.A. Anwar P. 2011. Manajemen Sumber Daya Manusia Perusahaan. Bandung: PT. Remaja Rosda Karya.

McPheat, Sean. 2010. Emotional Intelligence. UK: MTD Training.

Moeheriono, 2009. Pengukuran Kinerja Berbasis Kompetensi. Jakarta: Ghalia Indonesia.

Rivai, Veithzal dan Ella Jauvani. 2011. Manajemen Sumber Daya Manusia untuk Perusahaan. Jakarta: Raja Grafindo Persada.

Sedarmayanti. 2009. Sumber Daya Manusia dan Produktivitas Kerja. Bandung: Mandar Maju

2014. Manajemen Sumber Daya Manusia: Reformasi Birokrasi dan 
Manajemen Pagawai Negeri Sipil. Bandung: Refika Aditama.

Simamora, Henry. 2007. Manajemen Sumber Daya Manusia. Yogyakarta: STIE YKPN.

Stein, S. J. \& Book, H. E. 2002. Ledakan EQ 15 Prinsip Dasar Kecerdasan Emosional Meraih Sukses. Penerjemah: Trinanda Rainy Januarsari dan Yudhi Murtanto. Bandung: Kaifa

Sugiyono. 2011. Metode Penelitian Kuantitatif, Kualitatif dan $R \& D$. Bandung: Alfabeta. 2013. Metode Penelitian Bisnis. Bandung: Alfabeta.

Suwatno, dan Donni Juni Priansa. 2011. Manajemen SDM dalam Organisasi Publik dan Bisnis. Bandung:J Alfabeta.

Swasto, Bambang. 2003. Pengembangan Sumber Daya Manusia Pengaruhnya Terhadap Kinerja Dan Imbalan. Malang: Bayumedia.

Wibowo. 2013. Perilaku dalam Organisasi.Jakarta: PT. Raja Grafindo Persada.

. 2012. Manajemen Kinerja. Jakarta: PT. Raja Grafindo Persada.

Wungu dan Brotoharjo. 2003. Tingkatkan Kinerja Perusahaan Anda Dengan Merit Sistem. Jakarta: PT. Raja Grafindo Persada.

Ahangar, Reza Gharoie. 2012. Emotional Intelligence: The Most Potent Factor of Job Performance Among Executives. Emotional Intelligence - New Perspectives and Applications. 122-138.

Garkaz, Mansour dan Morteza Mehrvarzi1. 2012. Examining the Relationship between Emotional Intelligence and Brokerage Firms' Performance in Tehran Stock Exchange. International Research Journal of Applied and Basic Sciences. 3, (4), 886890.

Jorfi, Hasan dkk. 2010. Impact of Emotional Intelligence on Performance of Employees. Postmodern Openings. 1, (4), 63-74.

Kahtani, Ali Al. 2013. Employee Emotional Intelligence and Employee Performance in the Higher Education Institutions in Saudi Arabia: A Proposed Theoretical Framework. International Journal of Business and Social Science. 4, (9), 80-95.

Labbaf, Hasan, dkk. 2011. The Impact of the Emotional Intelligence on Dimensions of Learning Organization : The Case of Isfahan university. Interdisciplinary Business Research. 3, (5), 536-545.

Maryam, Shemshadi Vayghan, dkk. 2013. The Relationship between Emotional Intelligence and Job Performance of Faculty Members. International Journal of Basic Sciences \& Applied Research. 2 (6), 589-593.
Shahhosseini, Mohmmad. dkk. 2012. The Role of Emotional Intelligence on Job Performance. International Journal of Business and Social Science. 3, (21), 241246.

Yadav, Nidhi. 2011. Emotional Intelligence and Is's Effects on Job Performance: A Comparative Study on Life Insurance Sales Professionals. International Journal of Multidisciplinary Research. 1, (8), 248260.

Ansen, Yopines. 2004. Pengaruh Pengembangan Sumber Daya Manusia dalam Meningkatkan Kinerja Perusahaan. Bandung: Universitas Pendidikan Indonesia.

Sesilia, Dwi Rini W. 2011. Analisis Pengaruh Kecerdasn Emosional dan Spiritual Terhadap Kinerja Karyawan. Semarang: Universitas Diponegoro.

Yunilda. 2013. Pengaruh Kompetensi Sosial dan Kecerdasan Emosional Terhadap Kinerja Karyawan.Bandung: Universitas Widyatama. 